DE

DE GRUYTER

OPEN

Journal of Intercultural Management

Vol. 7, No. 2, June 2015, pp. 21-29

DOI 10.1515/joim-2015-0008

Zbigniew Bochniarz ${ }^{5}$

University of Washington

Jacek Lipiec 6

Warsaw School of Economics

\title{
Weyerhaeuser: A Good Reputation Instilled in Culture
}

Abstract: The paper addresses the concept of Weyerhaeuser's culture which was transformed as the result of mergers and implemented policies against recession. The culture, particularly their long-term vision and values played a crucial role in Weyerhaeuser's company. Frederick Weyerhaeuser, founder of the firm, realized that a firm's reputation was the most important asset. Significant increases in housing demand over 1997-2005 had led to an enormous pressure for faster deliveries and innovations in the construction industry. Weyerhaeuser decided to become global leader by transforming its culture and launching the iLevel concept ${ }^{7}$.

Key words: corporate culture, family firm, Weyerhaeuser.

This is not for us, nor for our children - but for our grandchildren Frederick Weyerhaeuser, 1900

\section{Introduction}

The story of Weyerhaeuser begins with Frederick Weyerhaeuser who came to America from Germany in 1852. Although he was working as a simple laborer, he succeeded in each job he undertook. Asked whether he is a lucky in all these successes he simply replied (Robertson 2011): “The secret lay simply in my will to work. I never watched the clock and never stopped before I had finished what I was working on". Frederick Weyerhaeuser teamed up with 15 partners with whom

\footnotetext{
${ }^{5}$ zbigb@uw.edu
}

${ }^{6}$ jlipiec@sgh.waw.pl

${ }^{7}$ The authors would like to express their gratitude to Weyerhaeuser Company for providing the data. This paper was possible due to the mutual cooperation between University of Washington and Warsaw School of Economics. 
he decided to purchase 900,000 acres of timberland from the Northern Pacific Railway in 1900 (Company information). This was the largest private transaction in USA at that time. Frederick Weyerhaeuser proposed to name the partnership as "The Universal Timber Company" but the partners opposed and suggested to name it after his name. Frederick Weyerhaeuser kept his profile very low and only three years before his death America discovered him and his achievements.

Today Weyerhaeuser is headquartered in Federal Way, away from the downtown of Seattle. The firm's brand may not be as well recognized as Seattle's megastars Microsoft or Amazon, although its revenues put it in the similar ranking of Fortune 500. In addition, Weyerhaeuser is also a public company as its Seattle's peers (it went public in 1963). Dan Fulton, CEO of Weyerhaeuser rephrases it as follows [Working Together to Release Our Potential 2008]: “...Many young people are surprised to know that we're a Fortune 150 company — or that, based on revenues, we rank right behind Costco and Microsoft on For-tune's list of leading companies headquartered in Washington. Yes, our sales put us ahead of Amazon, Starbucks or Nordstrom — all household names in Seattle". In 2012, Weyerhaeuser reported $\$ 7.1$ billion in net sales with the employment of 13,200 . The firm operates in four segments: timberlands, wood products, cellulose fibers and real estate.

As the result of "housing bubble" construction companies in U.S. have faced a tremendous demand for building houses in 2005 - doubled since 1997. This boom has influenced the methods of building houses and also pushed suppliers for searching new materials. As a consequence, construction firms intended to construct more houses in fewer time to satisfy the increasing demand. Weyerhaeuser aimed at taking a leading role in satisfying this demand.

The quick response to the market challenges may be attributed to the change in the Weyerhaeuser's culture. The firm's culture model is termed as iLevel culture and proved to be effective during the economic downturn in 2007 which severely affected the housing market. Weyerhaeuser not only survived this tough time but has increased its market share as well.

\section{Frederick Weyerhaeuser}

Frederick Weyerhaeuser or according to his original German name - Friedrich Weyerhäuser - was born in 1834 in Nieder-Saulheim. Being poor, he decided to come to America to improve the wellbeing after his father's death in 1852 . He started working at brewery, then in construction industry and finally got job at a sawmill. His performance in the sawmill was extraordinary and soon he was promoted to a salesman position. Soon his new skills were noticed and appreciated and he was sent to manage a newly opened sawmill in Rock Island County (Illinois). The sawmill got into financial troubles and Frederick Weyerhaeuser decided to buy it for himself and his brother-in-law Frederick Denkmann. They were offered the 
purchase of the sawmill due to their good reputation, honesty and trustworthiness. However Frederick was undisputable leader. They were running the joint business until 1900 when Frederick Weyerhaeuser founded the Weyerhaeuser company.

Frederick was a modest man, completely devoted to his work - spending long hours at his job. He had no addictions (drinking or smoking) and work was his only amusement as he used to say. Apart from work devotion, he had genial business instincts and appreciated trust. This may explain why most of his employees stayed with him over thirty years in the business. Asked about the business success he replied [New York Times 1914]: "I think I have succeeded because I care more for my credit than for my clothes". Indeed, Weyerhaeuser's success was built on fostering a good reputation since the beginning. Although a composition of different elements of his corporate culture had been changed many times, the good reputation remained the unchanged pillar of the firm. Frederick Weyerhaeuser stressed the importance of reputation as follows [Twining 1997, p. 85]:

Must be made - can not be inherited.

Is often times the best friend we have.

Is worth too much to be risked for the sake of money.

Will pay big dividends if we take an interest in it.

It the best antidote in the world for circumstantial evidence.

Must be earned - can not be bought.

Is soon lost among bad companies.

Weyerhaeuser was aware that a reputation may be a true asset in turbulent times. If once lost, a recovery of good reputation may take decades. It is especially important when a firm becomes branded by family's name. Frederick Weyerhaeuser was very careful in raising his children. He knew, they could be easily spoiled because of his wealth thus he made efforts to equip them with industry and honesty. He also provided them with education, something that he was missing because of his family poor standing (when his father was dead he quit school at age of twelve). For that reason, his children went to the family business after they completed their education.

\section{Weyerhaeuser's Culture}

A good reputation may result from using a family name as brand. A family would intend to perform as best as possible to keep its family brand respected. Kotler et al. [2009, p. 421] perceive this approach as preserving a strong brand and defines it as follows: „Vision, mission and success of a company in developing and offering purchasing experiences that deliver high levels of customer-perceived value". As a consequence, a reputable name reinforces purchasing experiences of clients that 
may bring profits even in turbulent times. In addition, vision is the key element in constructing a firm's culture.

The concept of corporate culture needs to be explained before digging into the Weyerhaeuser's culture. De Witte van Muijen [1999, p. 498] have presented their model of the organizational culture based on their vast consulting work. They argue the process of building the firm's culture begins with an interaction between individual and organization (see Figure 1). There are many forces which exert its power on the shape of the organizational culture. Firm's founders with their vision play key roles in this process. Weyerhaeuser's vision reads as follows (Firm source): "Our vision is to deliver superior sustainable solutions for the world. We do this through strong leadership, unwavering values, and a talented employee base". Based on this vision, the management sets the direction in which a firm follows. In particular, a way of performing tasks contributes influences the effectiveness of process. Leaders are responsible for this overall process because they are mandated by owners to follow their vision. As a consequence, this vision is translated into everyday firm's activities. Other factors which influence firm's culture come from stakeholders, associations. Even crises impact the culture. If fact, this is the crisis which forces a firm to change its routines because if a firm does not react to market turbulences then may disappear from the market. Lastly, the organizational culture impacts the national culture.

Figure 1. A conceptual model for understanding organizational culture

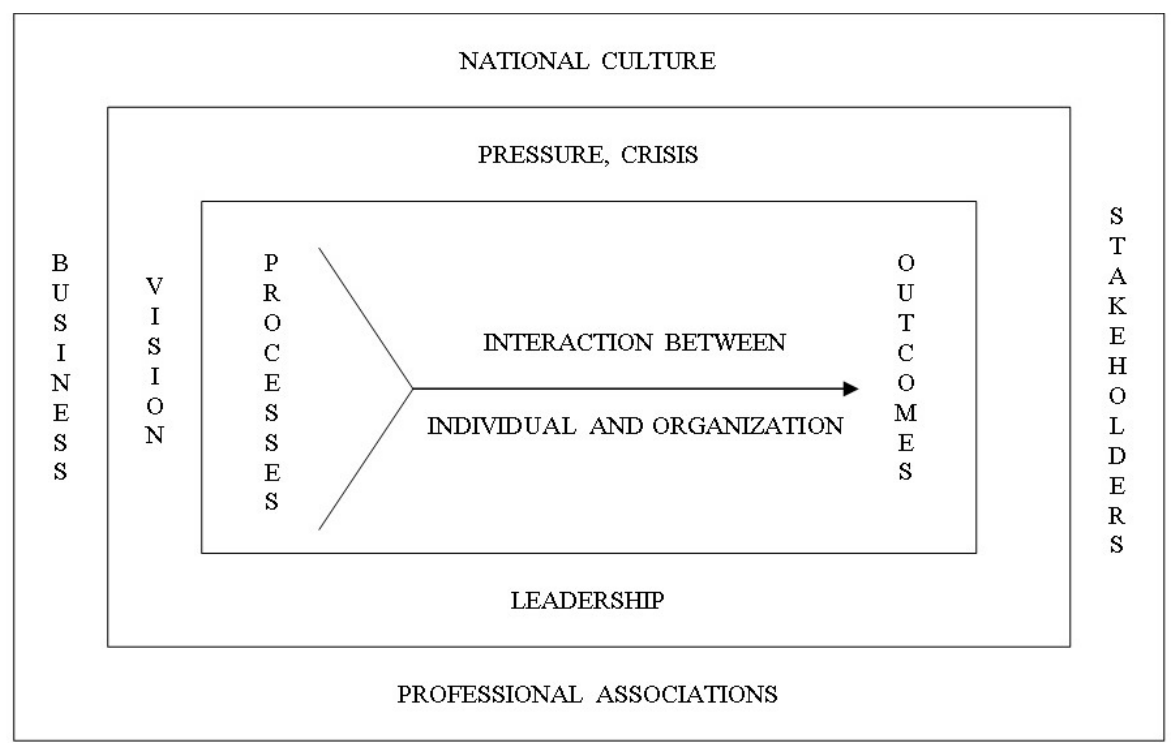

Source: De Witte K., van Muijen J.J. 1999, p. 498. 
Weyerhaeuser's culture was shaped by many different factors. Clients and their changing needs were primary factor in shaping their culture. As mentioned earlier, the downturn in 2007 had a tremendous impact on the whole industry. However Weyerhaeuser has decided to use this unfavorable event as an opportunity to change the whole industry. In fact, this process of change has begun in Weyerhaeuser earlier in 2005 with the consolidation of five product-line businesses. This process was necessary as the firm acquired three companies. The responsibility for the change rested on the cross-functional teams. In particular, their primordial task was to define roles, responsibilities and relationships or "3Rs" as it was shortly termed.

In the conceptual model of organizational culture (see Figure 1) leadership exerts the important role in fostering firm's culture. The leadership team was recruited from the Weyerhaeuser's family. In particular the next generation family members were invited to this team. The selection process of the next gens candidates was run by the HR department while the final decision was made by CEO. Next the key leadership positions were filled out and 300 leaders in total were placed. The entire process of changing Weyerhaeuser's organization culture was termed "iLevel" (see Table 1).

Table 1. From Multiple Cultures to ONE iLevel Culture

\begin{tabular}{|l|l|l|l|l|}
\hline Direction & Culture A & Culture B & Culture C & iLevel \\
\hline Strategy & $\begin{array}{l}\text { Sell First („,highly } \\
\text { specialized”) }\end{array}$ & $\begin{array}{l}\text { "Value added“ } \\
\text { (slightly } \\
\text { differentiated) }\end{array}$ & $\begin{array}{l}\text { Manufacture } \\
\text { First } \\
\text { („low cost } \\
\text { commodity } \\
\text { producer”) }\end{array}$ & $\begin{array}{l}\text { Demand (sell) } \\
\text { \& Supply } \\
\text { (make) in } \\
\text { Balance Across } \\
\text { Product Lines }\end{array}$ \\
\hline Customers & Builders & Dealers & 3rd Party & $\begin{array}{l}\text { Market to } \\
\text { Builders, Sell } \\
\text { to Dealers }\end{array}$ \\
\hline Expertise & $\begin{array}{l}\text { Product Experts } \\
\text { (build to exceed } \\
\text { expectations) }\end{array}$ & $\begin{array}{l}\text { Process } \\
\text { Experts (meet } \\
\text { everyone's } \\
\text { expectations) }\end{array}$ & $\begin{array}{l}\text { Experts (meet } \\
\text { the minimum } \\
\text { expectations) }\end{array}$ & $\begin{array}{l}\text { Exoduct } \\
\text { Epplication } \\
\text { products to } \\
\text { solve customer } \\
\text { problems) }\end{array}$ \\
\hline Engineering & $\begin{array}{l}\text { Innovators (new } \\
\text { products, new } \\
\text { equipment) }\end{array}$ & $\begin{array}{l}\text { Shoppers } \\
\text { (standard } \\
\text { products, new } \\
\text { equipment) }\end{array}$ & $\begin{array}{l}\text { Creatures of } \\
\text { habit (standard } \\
\text { products, } \\
\text { standard } \\
\text { equipment) }\end{array}$ & $\begin{array}{l}\text { Innovative } \\
\text { product } \\
\text { Reliable } \\
\text { process } \\
\text { Effective } \\
\text { project }\end{array}$ \\
\hline
\end{tabular}




\begin{tabular}{|l|l|l|l|l|}
\hline $\begin{array}{l}\text { Dealing } \\
\text { Internally }\end{array}$ & $\begin{array}{l}\text { NO }=, \text { Back } \\
\text { to the drawing } \\
\text { board” }\end{array}$ & $\begin{array}{l}\text { NO }= \\
\text { Maybe” }\end{array}$ & $\begin{array}{l}\text { NO = „What } \\
\text { part of no } \\
\text { don't you } \\
\text { understand?" }\end{array}$ & $\begin{array}{l}\text { NO = Come } \\
\text { back with } \\
\text { a better idea! }\end{array}$ \\
\hline Decision Making & $\begin{array}{l}\text { "Entrepreneurial”" } \\
\text { (one leader } \\
\text { decides) }\end{array}$ & $\begin{array}{l}\text { Consensus } \\
\text { (Everyone } \\
\text { decides) }\end{array}$ & $\begin{array}{l}\text { "Willamette } \\
\text { Way” Every } \\
\text { leader decides }\end{array}$ & $\begin{array}{l}\text { Leaders Decide } \\
\text { (balance speed } \\
\text { with input) }\end{array}$ \\
\hline Communications & $\begin{array}{l}\text { Wide Open } \\
\text { leader's message) }\end{array}$ & $\begin{array}{l}\text { „confidential” } \\
\text { meant } \\
\text { everyone reads } \\
\text { it!) }\end{array}$ & $\begin{array}{l}\text { Guarded } \\
\text { (chose not to } \\
\text { communicate } \\
\text { some items) }\end{array}$ & Open \\
\hline
\end{tabular}

Source: Bradsbaw A. 2007, p. 49.

The acronym iLevel was derived from construction terminology and values represented by Weyerhaeuser. "Level" refers to levels in buildings and paraphrases that all levels of a building have to be even to be stable. "I" stands for integrity and innovation as the key value drivers for the firm. Weyerhaeuser has also stressed the importance of time in the plan execution. The leadership has been allotted 90-day action plans to implement all activities.

The process of cultural change had been executed in many directions beginning with a strategy to communication. A strategy was centered around the selling process. In particular, sales representatives were encouraged to solve clients' problems because of their deep knowledge of the firm. On the other hand the decision making process was transferred to leaders who were empowered to take responsibility for the implementation and development of processes.

Table 1 illustrates the cultural transition process in Weyerhaeuser. Before launching iLevel there were three different competitive cultural models. The firm has been experiencing fierce competition among these cultures to be dominant. Despite several attempts to integrate all these competitive cultures into one in the past it did not happen. A difficulty stemmed from different values, beliefs and behavior of employees and these cultural elements were hard to change.

The management of Weyerhaeuser had witnessed how these three competitive cultures led to the firm's underperformance. Somehow it was the fierce and even lethal rivalry inside the firm of being the best but in different strategies. For the culture A employees were focused on selling, in culture B on adding value and in C on manufacturing as priority. The innovative approach Weyerhaeuser implemented was about the culture identification through the iLevel brand. The key culture components were structured and described to arrive at the concept of the brand promise. These components of the brand promise were: (1) integrity, (2) marketdriven, (3) innovation, and (4) performance. Table 2 presents these components cascaded to norms and expected behaviors. 
Table 2. Culture components

\begin{tabular}{|c|c|c|}
\hline Values & Norms & Behaviors \\
\hline Integrity & $\begin{array}{l}\text { Safety is always more important than } \\
\text { production \& sales. } \\
\text { Financial responsibility. } \\
\text { We keep our word. }\end{array}$ & $\begin{array}{l}\text { I care about consequences of } \\
\text { unsafe behavior and conditions } \\
\text { and act upon them ... every } \\
\text { time. } \\
\text { I never compromise } \\
\text { Weyerhaeuser ethical business } \\
\text { standards. } \\
\text { I deliver what I promise. } \\
\end{array}$ \\
\hline $\begin{array}{l}\text { Marker } \\
\text { Driven }\end{array}$ & $\begin{array}{l}\text { Focus on customer value, not what's } \\
\text { easiest for the company. } \\
\text { Make disciplined choices driven by the } \\
\text { value proposition. } \\
\text { We are easy to do business with. }\end{array}$ & $\begin{array}{l}\text { I find solutions by deeply } \\
\text { understanding the nature of our } \\
\text { customer's business. } \\
\text { My decisions are driven by } \\
\text { safely delivering the five value } \\
\text { proposition experiences. } \\
\text { „That's not my job” does not } \\
\text { exist! }\end{array}$ \\
\hline Innovation & $\begin{array}{l}\text { Every associate has the freedom to } \\
\text { innovate. } \\
\text { Ten percent of our sales come from } \\
\text { products or services }<5 \text { years old. } \\
\text { We improve the design of existing } \\
\text { products, services, and work processes. } \\
\text { We create breakthrough opportunities } \\
\text { for new products \& services. }\end{array}$ & $\begin{array}{l}\text { I support the exchange of ideas } \\
\text { and lessons learned. } \\
\text { I recognize and reward ideas that } \\
\text { add value or eliminate waste. } \\
\text { I take disciplined risk when } \\
\text { investing in products and } \\
\text { solutions. } \\
\text { I constantly look for nevi' ways } \\
\text { to improve our customer's } \\
\text { efficiency. }\end{array}$ \\
\hline Performance & $\begin{array}{l}\text { Associates can deliver more than they } \\
\text { think they can. } \\
\text { We are the structural frame experts. } \\
\text { Our products and solutions work... } \\
\text { every time! }\end{array}$ & $\begin{array}{l}\text { I reduce hassle in doing business. } \\
\text { I develop my skills and support } \\
\text { the development of others. } \\
\text { I act with speed, simplicity', and } \\
\text { decisiveness. } \\
\text { I hold myself and others } \\
\text { accountable for these behaviors. }\end{array}$ \\
\hline
\end{tabular}

Source: Bradsbaw A., 2007, p. 50.

The executives were then verified with all values. Some recognized that were sticking to the old culture but also were aware that new culture had to be dominant. To reinforce the importance of the new culture the firm decided to make a huge visibility by engaging in sponsorship events of NASCAR (National Association for Stock Car Auto Racing - Narodowa Organizacja Wyścigów Samochodów Seryjnych) and Extreme Makeover/Home edition.

The brand promise was widely accepted in Weyerhaeuser. De Witte K. and van Muijen in their cultural model perceive the interaction between processes and 
outcomes as the critical for culture building. Undoubtedly outcomes should be directed towards not only firm's clients but stakeholders as well. The new iLevel culture has helped company to simplify and improve the process of service client. In addition, the culture has contributed to wide array of improvements as [Bradsbaw 2007, p. 51]:

- Reduced time, labor, and callbacks when building homes.

- Optimized structural frame and reduced waste.

- Streamlined design customization (through innovative software).

- Efficient, reliable delivery of products \&c services.

- Simplify the way business is done.

\section{Concluding remarks}

Efforts to change a corporate culture may take a long time because it is about changing values. Such a change takes a lot of time and fails in many cases. This process was not arduous in case of Weyerhaeuser because the firm relied on honesty and integrity as the key principal values since its founding.

Weyerhaeuser has decided to act with dedication and with a huge coverage. Achievements were excellent because by implementing iLevel culture Weyerhaeuser was able in increase the product penetration in the construction industry. In fact, the firm increased the penetration by 5\% in 2006 and that was the biggest leap in the firm's history. The team responsible for the implementation of iLevel has been recognized by the Weyerhaeuser's officers and won the prestigious Weyerhaeuser President's Award.

\section{References}

Bradsbaw A. (2007), How HR Helped Weyerhaeuser's Extreme Makeover, "Human Resource Planning", Vol. 30, no. 4.

De Witte K., van Muijen J.J. (1999), Organizational Culture: Critical Questions for Researchers and Practitioners, "European Journal of Work and Organizational Psychology", Vol. 8, no. 4.

Healey J., Miller C. (2013), Frederick Weyerbaeuser and the American West, Minnesota Historical Society Press.

Hidy R.W., Hill F.E., Nevins A. (1963), Timber and men. The Weyerhaeuser story, Macmillan, New York.

Kotler P., Keller K.L., Brady M., Goodman M., Hansen T. (2009), Marketing management, Pearson Education Limited.

Michaelis L.O. (1998), Making a difference at Weyerhaeuser, "Business Economics", Vol. 33, Issue 3.

Perkins D.N.T., Holtman M.P., Kessler P.R., McCarthy C. (2000), Leading at the Edge: Leadership Lessons from the Extraordinary Saga of Shackleton's Antarctic Expedition, Amacom.

Robertson P. (2011), Titans of capitalism - Frederick Weyerbaeuser - The timber king, "Opportunist Magazine", July 26. 
Russell L., Reynolds J.J., Chadalavada S. (2004), Case study: how a Weyerhaeuser unit executed a winning strategy using Desert Storm's fast-cycle, strategic action approach, "Strategy \& Leadership", Vo.32, no.4.

Twining C.E. (1997), F.K. Weyerhaeuser: a biography, Minnesota Historical Society Press, St. Paul.

F. Weyerhaeuser, Lumber King, Dead (1914), "New York Times”, April 5.

Working Together to Release Our Potential (2008), Address by Dan Fulton, CEO, President, Weyerhaeuser Company, Delivered to Rotary Club of Seattle, Red Lion, Seattle, Washington. 